\title{
Private Liberal Arts Colleges and the Costs of Scientific Journals: A Perennial Dilemma
}

\author{
Paul D. Burnam
}

The continuing large increases in the costs of scientific journals is particularly acute in private, four-year liberal arts colleges. This study seeks to learn how academic librarians in these institutions are coping with the price increases. How do they inform and negotiate with their science departments in the face of inflated costs? What alternate strategies are employed to maintain access when local ownership becomes economically unfeasible? Using information obtained via questionnaire and personal interviews, this study describes how liberal arts colleges in the Midwest are confronting these challenges. The conclusion offers suggestions on how to manage a most vexing issue.

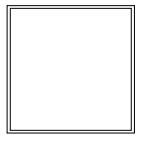

rivate, four-year liberal arts college libraries experience constant pressure from the rise in costs of journal subscriptions. Subscription prices for the periodical literature of all disciplines continue to escalate, but the rise is especially acute in the sciences. In his Library Journal article, "Serial Killers: Academic Libraries Respond to Soaring Costs," Paul McCarthy uses three scientific journals as examples. During the period 1989-1992, two of the titles almost doubled in price, and the third experienced a price increase of 66 percent. ${ }^{1}$ In Library Journal's 1997 Periodical Price Survey, the average cost per title by broad subject area shows scientific titles costing seven times more than arts and humanities titles and twice as much as social science titles. ${ }^{2}$ Why are there such disparities between the sciences and other disciplines? McCarthy says that it de- pends on whom one asks. Librarians do not hesitate to level charges of price gouging at scientific publishers. The spokesperson for one major publisher cites as major reasons a weakened exchange rate for the dollar and the explosion in sheer size of journals by five to ten times. Librarians counter that publishers are not as vigilant in screening out insignificant studies regarding the explosion in journal content. With regard to the exchange rate question, currency fluctuations are not running at 100 to 300 percent rates as the prices for some titles increased. Some librarians point to the publish-or-perish condition as another driving force of cost inflation. Publishers know that scholars need to publish so the provision of a vehicle to report scholarly research will likely outweigh costs. ${ }^{3}$

Shrinkage of academic library budgets adds to the pressure of rising costs.

Paul D. Burnam is a Public Services Librarian in Beeghly Library at Ohio Wesleyan University; e-mail: pdburnam@cc.owu.edu. 
Chestalene Pintozzi has pointed out that library budgets have been on the decline since the 1960 s. ${ }^{4}$ Of course, subscription rates for journals are not the only facets of academic life that have felt the impact of inflation. Across-the-board inflation, a reduced pool of potential students, heavier competition for grant funds, a greater demand for institutional financial aid, and other forms of reduced institutional revenue most definitely are trickling down to library budgets.

\section{Reasons for This Study}

The intent of this study was to survey how liberal arts college libraries are coping with the challenge of ever-increasing periodical prices in the sciences. Its impetus came from the author's assignment as departmental liaison to the botany/ microbiology and zoology departments at Ohio Wesleyan University. During the past academic year, several annual publications subscribed to by these departments experienced a twofold price increase. Because the serials budget did not experience an increase in 1996-1997, the departments had to drop certain titles in order to retain the titles they considered essential. A very careful process of answering departmental questions about funding possibilities and alternate courses of action followed. These circumstances proved to be very small in scale compared to a larger elimination of titles due to cost increases that had occurred four years previously. The titles the departments decided to eliminate were those judged to be nonessential to the curriculum or research.

As a result, the approach of similar liberal arts college libraries to this issue seemed to possess merit. The project became the focus for a study leave during the summer of 1997 . The study focuses on two aspects of this issue in particular. One aspect is how the library communicates and negotiates with the science departments when price increases require budgetary adjustments. How formal or informal is the process? How are the realities of canceling periodical titles accepted? Do the library and/or the departments use specific tools to execute the process? The second aspect is how such institutions address the ownership/access issue. Do they enter consortial agreements in which individual member libraries take responsibility for building collection strength in specific disciplines to benefit the consortium as a whole? Do they make changes in the way they support and manage interlibrary loan or document delivery? How do they implement electronic databases and use them to address this issue? Is the subscription rate for electronic journals more manageable than for their print equivalents?

\section{Methodology}

A survey instrument of twenty-one questions addressing the issues of journal price increases was created. It focused on the library/departmental process for reconciling budget shortfalls, influence of accreditation criteria, the library's position on access and ownership considerations, the effect on interlibrary loan and documents delivery services, interlibrary cooperative purchasing, and the library's approach to electronic full-text versions of the literature. The author decided to blend both quantitative and qualitative means of data collection into the study. Such a combination of research methodology serves to provide objective information about how each library manages scientific journal price increases and subjective information as to the reaction on each campus to these developments. The findings show, for example, how many libraries had to eliminate titles from their science collections over the past five years, how many have a formal process for resolving the impact of price increases, and how many are turning to electronic forms of the literature. The questionnaire served to provide these data. In addition, interviews were conducted with the library director, the science librarian, or the 
serials librarian at twelve libraries to hear how they confront these forces. All participants received assurances about protecting the confidentiality of their remarks. The interviews provided the source for specific examples of how each campus is addressing these issues and seeking solutions. Member libraries of three midwestern liberal arts college associations received the survey: The Associated Colleges of the Midwest, East Central Colleges, and the Great Lakes Colleges Association.

Initially, the questionnaire went to the library director. The director had the option of delegating it to the staff member responsible for liaison with the science departments. Thirty-two institutions made up the sample, but that number was reduced to thirty-one when it became clear that one library represented the undergraduate college of a major research university with many departmental libraries available to both undergraduate and graduate students. Nineteen academic libraries received the questionnaire through the mail, accompanied by a stamped, self-addressed envelope. Geographic proximity determined which libraries received questionnaires only in contrast to those visited for interviews. Those library directors who agreed to be interviewed also received a questionnaire as preparation for an interview meeting. The libraries in figure 1 participated in the study by either completing and returning the questionnaire or agreeing to an interview.

Four weeks after the questionnaires went out, postcards were sent to remind recipients to return them within three weeks. Interviews with the director and/ or other designated staff member(s) proved very beneficial. Follow-up questions identified threads to follow that were not initially apparent. Discussions about the impact of accreditation for American Chemical Society (ACS)-sanc-

\section{FIGURE 1 \\ Participating Libraries}

Albion College

Antioch College

Baldwin-Wallace College

Beloit College

Bethany College

Capital University

Carleton College

Coe College

Colorado College

Depauw University

Earlham College

Grinnell College

Heidelberg College

\author{
Hiram College \\ Hope College \\ Kalamazoo College \\ Lake Forest College \\ Lawrence University \\ Mount Union College \\ Muskingum College \\ Oberlin College \\ Otterbein College \\ St. Olaf College \\ Wabash College \\ Westminster College
}

tioned majors, efforts to wire and automate campuses, bibliographic instruction, and the nature of the campus computer infrastructure occurred frequently. During one visit, the author was invited to attend the luncheon meeting of one college's Friends of the Library organization. It was fortuitous to witness what an active and dedicated friends group can do. These opportunities to hear from the interviewees about subscription issues turned out to be most revealing and thought-provoking. It became apparent that the issue of rising costs for scientific journals in liberal arts curricula is significant and revealed a problem currently without immediate answers.

The spirit of fairness dictated that publishers also be included. Thus, attempts were made to reach four publishers of scientific literature. Telephone interviews were conducted with marketing representatives and/or documentation was received from them describing the publishers' perspective. This additional aspect to the study proved valuable because it further illuminated what had been found earlier in the library literature about the publishers' positions. ${ }^{5}$ In addition, the director of a statewide consortium of fourand two-year colleges and university libraries was contacted to obtain his opinion and suggestions. He expressed the 


\begin{tabular}{|lc|}
\hline \multicolumn{2}{|c|}{ TABLE 1 } \\
Over the Past Five Years, Has Your \\
Scientific Journal Collection Met \\
Student, Faculty, and Staff Needs? \\
\hline \hline \\
Response & No. of Respondents \\
\hline Increased & 4 \\
Decreased & 9 \\
Remained the same & 10 \\
\hline
\end{tabular}

belief that such colleges should continue to participate and support involvement in consortia. Moreover, he sent a conference paper detailing how his organization is dealing with the issue.

\section{Findings}

Of the thirty-one libraries contacted for the study, twenty-five participated by either returning the questionnaire or agreeing to interviews. The following tables represent the responses to the distinct choices offered for many of the questions in the questionnaire. The text following each table offers analysis and comments received during the interviews to further explain the quantitative findings.

As the responses in table 1 suggest, collection development regarding scientific literature shows little forward motion. Two distinct approaches to answering this question at the libraries were presented where staff were interviewed. One group tried to put its situation in the best possible light. Some members of this group answered that they were surpassing or holding steady in meeting student and faculty needs. Only one librarian who indicated an increase in ability to meet curricular needs explained in any detail how it happened. His college's science curriculum focuses on preparing mathematics and science teachers for secondary schools. The chemistry department at this college had dropped its ACS-accredited major. The director characterized the library's priority for resources as moving slowly toward access with a definite interest in more electronic full-text data- bases. Another director explained that the local collection was insufficient to meet all faculty and student needs. Close proximity (less than one mile) to a large public university and the library of a major pharmaceutical manufacturer overcomes the collection's deficiencies.

Many of the respondents were maintaining the status quo. They explained that any science faculty requests for new titles had to accompany recommendations to drop titles judged not to be contributing to the collection's content. Another director who identified with the status quo group said his library received enough funds to maintain a core collection. In addition, it was becoming increasingly dependent on document delivery. One librarian explained that her college depended significantly on gift issues from the faculty, an arrangement that strongly supplemented the titles to which the library subscribed. In this arrangement, a faculty member subscribes individually to a title. When he or she finishes using the issue, it is submitted as a gift and added to the library collection. This is not an uncommon practice, but this study participant was the only one who showed a degree of dependence on such an arrangement. Some journals do specify a period during which individual subscribers cannot donate issues to the library. Several titles at this college fall into this category. In view of this circumstance, a gap will occur between the most recent issue in the library and the issue that has been published most recently.

The other type of answer came from directors and science librarians who

\begin{tabular}{|c|c|}
\hline \multicolumn{2}{|c|}{$\begin{array}{c}\text { TABLE } 2 \\
\text { How Do the Rising Costs of Scientific } \\
\text { Journals Influence Your Response to } \\
\text { the Question in Table 1? }\end{array}$} \\
\hline Response & No. of Respondents \\
\hline Very much & 16 \\
\hline Very little & 6 \\
\hline
\end{tabular}




\begin{tabular}{|c|c|}
\hline \multicolumn{2}{|c|}{$\begin{array}{c}\text { TABLE } 3 \\
\text { In Response to the Rising Costs of } \\
\text { Scientific Journals, Has Your } \\
\text { Library Had to Cancel Titles? } \\
\end{array}$} \\
\hline Response & No. of Respondents \\
\hline Yes & 20 \\
\hline No & 3 \\
\hline
\end{tabular}

readily pointed out the decline of their science collections. Several freely admitted that they need assistance in expressing to faculty and academic administrators how acute the situation is. Many expressed the hope that this study might help bolster their arguments. Four directors in this category said they received marginal or no increase in their budget during the past five years. One is looking at a 15 percent decrease in his periodical budget for 1997-1998. Another director, who is working without any increase in her materials budget, said the science department chairs were less than understanding when she sent out memorandums explaining the situation. Indeed, a science chairperson at that college even contacted the college president, asking, "What is this all about?" One director described how he and the science faculty worked through two rounds of title cancellations in the past seven years. He characterized the current collection as representing core titles and expressed the fear that another round of cancellations in two to three years would mean elimination of some core titles unless the budget increases. Because of the above data, most participants in this study were either barely holding steady or declining in their ability to support their colleges' curricula.

According to table 2, most respondents asserted that rising costs had a direct and definite effect. Seven characterized the situation as one of stagnation in terms of advancing their science journal collection. Only two schools said their administrations responded with additional funds to continue collection growth. One of these is looking forward to a 17 percent serials budget increase for the 1997-1998 fiscal year after several years of decline. The library achieved such a notable victory by using statistics showing how its periodical expenditures ranked in the lower portion of the Great Lakes College Association.

As table 3 shows, most of the libraries had to eliminate journal titles in the past five years. Four colleges described a quid pro quo arrangement for managing the problem. If a department wished to add a new title, it had to select one to cancel. In two schools, cancellations take place in all departments to maintain a degree of fairness in resolving such an undesirable situation. Here, the concept of fairness is debatable because departments that subscribe to very few journals must make cancellations, as well as those with a long subscription list. "Reluctant compliance" and "not happy, but understanding" characterized the remarks summing up faculty reaction. During three of the interview visits, the director or science librarian related how the faculty were unaware of the difference between institutional and individual subscription rates. The faculty at these colleges thought only in terms of the individual rate. Of course, the difference between individual and institutional rates can be significant. In the case of BioScience for 1996, the individual price is $\$ 60$, compared to the modest institutional rate of $\$ 165 .{ }^{6}$ A more noteworthy example is the Journal of the American Chemical Society. The individual price comes to an expensive, but manageable, $\$ 125$, whereas the institutional rate skyrockets to $\$ 1,695$. $^{7}$ Such a price differential truly drives home the significance between individual and institutional rates.

Table 4 offered very illuminating commentary. Sometimes the director bears the news to the department chair, and together they decide what titles to eliminate. At one institution, the director makes the case for cancellations to the library advisory com- 


\begin{tabular}{|c|c|}
\hline \multicolumn{2}{|c|}{$\begin{array}{c}\text { TABLE } 4 \\
\text { Does Your Library Have a Formal } \\
\text { or Informal Process for Communi- } \\
\text { cation/Negotiation with Academic } \\
\text { Departments in Dealing with } \\
\text { Journal Price Increases? } \\
\end{array}$} \\
\hline Response & No. of Respondents \\
\hline Formal & 2 \\
\hline Informal & 16 \\
\hline
\end{tabular}

mittee. From the committee, news of the need to eliminate titles circulates to all the departments. The process at another campus has the director communicating to each department a target percentage that must be cut. After the department becomes aware of the targeted amount, negotiations between the library director and the department proceed until they agree. In another example, the director decides what titles to cut, and the department is informed after the fact.

One director begins the process by asking his acquisitions librarian to prepare a list of each department's journals and their current prices. When the list is ready, the library director meets with the department chairs individually, typically recommending that they drop a title or two to keep pace with inflation. The chairs are asked to hold meetings with their colleagues to discuss use versus cost and then to report their decision to the director within two to three weeks. In the event the departments' decision is to drop no or too few titles, the director decides what to cut, based on usage and cost. He reports that the library and the faculty engaged twice in a review of journal titles in the past seven years. This library director feels the scientific journal collection is at its essential core. In two or three years, when the next collection review becomes necessary, any cuts required will hurt because core titles will face cancellation.

At another school, the acquisitions librarian compiles data on the usage and costs of a department's subscriptions. Then, in a departmental meeting, the faculty decides which titles to cancel. At yet another campus, the director communicates the journal situation to affected departments by e-mail. Decisions to cancel go forward by means of electronic communication. In the case of one college, across-the-board cancellations became necessary. Librarians with departmental liaison assignments explained the impact to their respective departments. Each department was asked to eliminate ten percent of its periodical budget. Departments that did not comply with the ten percent request were asked to cancel at least one title from their subscription list.

Two colleges developed concise and well-constructed tools to assist the faculty in making cancellation decisions. At one school, the serials librarian prepared a title list of each department's subscriptions. The list also included the current price for the journal and usage statistics, the latter consisting of circulation and pickup figures for that title. Pickup data are based on in-house usage of a title; that is, copies of issues found off the shelf around the library are scanned by a bar code wand to determine how often that title was used in-house. The faculty then use those data in conjunction with their subject knowledge to decide which titles are expendable. At the other school, the director developed a title rating form for each department when a major cancellation took place in 1993. The list gives each title to which the department subscribes and its current price. Next to each title is a space to rate it on a scale of one to four. Each rating category is defined as follows:

1. Core: Journals that are integral to the discipline and likely to experience heavy use

2. Supporting: Journals that are closely related to the specific curriculum offerings of the department and are essential for the support of those courses

3. Peripheral: Interesting journals in a field which are not directly supportive of 


\begin{tabular}{|c|}
\hline TABLE 5 \\
Do Accreditation Pressures Play an \\
Important Role in the Level of \\
$\begin{array}{c}\text { Funding Budgeted for the Acquisi- } \\
\text { tion of Scientific Journals? }\end{array}$ \\
\hline \hline Response $\quad$ No. of Respondents \\
\hline Yes \\
No \\
\hline
\end{tabular}

the department's curriculum

4. Unimportant: Journals that do not support the curriculum

Bolstered by the data on these evaluation forms returned by each department, the library canceled enough titles to stay within the confines of its periodical budget that year. Currently, the library only notifies departments about possible cancellations when a subscription increases by more than 20 percent.

The question in table 4 offered an opportunity to think creatively about the best course of action in the event no process exists. Six directors commented on this issue, and their comments ranged from the whimsical to the serious. One director suggested that the business of resolving journal price increases be left to the college president. Another believed that in light of greater use of electronic journals, cancellation of print or microform double subscriptions deserved consideration. Other suggestions included decreasing the monograph allocation. At one college, the ideal solution would take the form of a sequence that begins with the cancellation titles of marginal value to the curriculum without departmental cooperation. Then the faculty would be given basically a blank check to order articles via a document delivery service as their needs dictated. One director described a plan to establish a core undergraduate collection, explaining how the libraries that belonged to the Oberlin Group within his state would develop a cooperative purchasing plan. This plan depended on the fact that Oberlin Group member libraries received a 55 percent discount on many journal titles. Another director proposed that an acrossthe-board review of all periodical titles take place every five years. At one library, the suggestion was to close the periodical stacks to obtain accurate usage statistics.

A slight majority of the respondents in table 5 described accreditation as an important influence on journal budgets. The accreditation body most frequently mentioned was ACS, which provides for a specially recognized major when colleges meet its criteria. In terms of journals, ACS accreditation can take up a significant portion of the journal budget. This circumstance occurs because a specific run of back files of issues must exist besides a current subscription. One director estimated the ACS segment of the journal budget for his institution at $\$ 20,500$, a situation that can cause some hard thinking. At schools where the directors discussed this circumstance, most graduated fewer than ten chemistry majors who opted for the ACS-recognized major. Therefore, this status for a handful of students is becoming an increasingly expensive proposition.

As table 6 shows, accreditation standards ran in favor of the negative. One director described the situation as a "racket," where the accreditation bodies also were the publishers of the journals they required colleges to own. A review of ACS's home page shows that it does address library guidelines for ACS-approved programs. Chemical Abstracts must

\begin{tabular}{|c|}
\hline \multicolumn{2}{c|}{ TABLE 6} \\
If You Answered Yes to the Question \\
in Table 5, Would You Characterize \\
That Influence As Positive or \\
Negative? \\
\hline \hline Response \\
\hline $\begin{array}{l}\text { Positive } \\
\text { Negative }\end{array}$ \\
\hline
\end{tabular}




\begin{tabular}{|l|}
\hline \multicolumn{1}{|c|}{ TABLE 7} \\
What Position Has Your Library \\
Taken on the Issue of Access and \\
Ownership with Respect to Scien- \\
tific Journals?
\end{tabular}

be accessible in either paper format or electronically. At the minimum, ACS requires libraries to carry subscriptions to twenty or more refereed journals. A minimum of fourteen journals in print is acceptable if the library can provide faculty and students with the means to gain access to the wider literature. Of those fourteen titles, four must be from the general chemistry content list and at least one each needs to come from the areas of analytical, biological, inorganic, organic, and physical chemistry. Of the fifty-five titles required, recommended, or suggested from the ACS list, nineteen are ACS publications. ${ }^{8}$

In analyzing the replies to the question in table 7, most respondents said they had not made a hard commitment either way. As indicated, the most frequent reply was that the library was trying to fulfill both approaches in supporting user needs. This answer was not an option on the original questionnaire. Most libraries maintain their existing print collections while adding new electronic services that are cost-effective and support the curriculum. One access proponent said his library could no longer afford to emphasize ownership. One respondent who said her library had not taken a position either way expressed the belief that technology was making access an option. However, she went on to say that copyright considerations prevented access from being a strong option.

Regardless of whether participants declared a commitment to ownership over access, several had an opinion on the substance of table 8 . Nine libraries declined to state a position on this question. There was wide disparity in the size of budgets among the libraries that participated. Participants were not pressed for their total journal budget, although a few volunteered this information. The range extended from more than $\$ 50,000$ to almost $\$ 900,000$. Despite the level of budgeting, most respondents said they could not close the gap between the dollars with which they had to work and the price increases created by publishers. One director confessed that he tried overspending annually in hopes of getting an increase from his administration. The result now is that he faces a 15 percent cut in his serials budget for the 1997-1998 academic year. Three libraries showed that they received sufficient funding to maintain their core collections and buy new titles as faculty requested. However, even in these cases, the directors suggested that the chances for collection growth were nonexistent.

Most respondents to a question regarding the impact on interlibrary loan (ILL) showed that their volume of activity had increased but that the rise did not relate conclusively to the cancellation of journal titles. At one library, the increase resulted from the inclusion of graduate programs in the curriculum. Another school belongs to a statewide network that offers a highly developed resource-sharing system. In one case, a library added a .5 FTE to manage the increased ILL traffic following entry into a

\begin{tabular}{|c|}
\hline \multicolumn{2}{|c|}{ TABLE 8 } \\
If You Answered Positively for \\
Ownership, Do You Believe Your \\
Library Is Receiving Sufficient \\
Budgetary Support to Maintain Its \\
Collection of Scientific Journals? \\
\hline \hline Response \\
\hline Yes \\
No
\end{tabular}




\begin{tabular}{|lc|}
\hline \multicolumn{2}{|c|}{$\begin{array}{c}\text { TABLE } 9 \\
\text { Document Delivery Vendors Used by } \\
\text { Participants }\end{array}$} \\
\hline \hline Response & No. of Respondents \\
\hline UMI & 8 \\
EBSCO & 1 \\
OCLC & 2 \\
Genuine Article & 1 \\
Uncover & 9 \\
British Library & 1 \\
None & 10 \\
\hline
\end{tabular}

statewide academic library network. One library that received no appreciable budget increase over the past five years during which $\$ 8,000$ worth of journal cancellations occurred saw its ILL activity go up 58 percent. Another library reported its staff recognized ILL requests for titles receiving cancellations.

Document delivery, a commercial service that duplicates journal articles and transmits them quickly to a customer by fax or express mail for a fee, serves as another access option on some campuses (table 9). However, it offers a last resort when urgency of need becomes the driving force. Respondents said that University Microfilms and Colorado Alliance of Research Libraries's (CARL's) Uncover was the service used most frequently. One library tried a major initiative of offering 24-hour access to document delivery to its faculty via fax. The library was willing to subsidize all requests for articles through this service. However, poor-quality fax transmissions proved the undoing of this plan. The faculty reacted by saying it preferred print subscriptions to such an alternative.

As table 10 shows, cooperative purchasing of scientific journals is an option whose time has yet to come. A sizeable majority of the respondents to this question had neither tried nor considered it, and those that had tried it experienced only minor success. Copyright implications killed interest in cooperative pur- chasing among East Central Colleges librarians. One library reported how one title purchased under a cooperative arrangement returned no benefit to its curriculum.

The question in table 11, which relates to materials formats for scientific literature, yielded no great surprises but did offer additional insights into the access versus ownership debate. All respondents replied that print was still their priority format. Two commented that online documents were growing in prominence but still placed a distant second to print materials.

The purpose of table 12 is to gauge where the thinking on this issue is going within the library community. Respondents placed electronic journals in the access column by a significant margin. The most illuminating observation on this question came from those participants who pointed out that access to back files of an electronic title is the deciding factor. If library users could still access back issues of an electronic journal even after cancellation of the current subscription, the library owned those issues. If all access ended with subscription cancellation, the electronic journal offered only access. The essence of this question will continue to evolve as new technological advances become known.

Concerning the full-text databases and/or electronic journals used by participants, there was no dominant vendor identified by the responses. The reasons given for the services offered most fre-

\begin{tabular}{|l|}
\hline \multicolumn{2}{|c|}{ TABLE 10 } \\
Has Your Library Made Any Efforts \\
in Cooperative Purchasing of \\
Scientific Journals with Other \\
Libraries? \\
\hline \hline \multicolumn{2}{|c|}{ No. of Respondents } \\
\hline Response \\
Yes \\
No \\
\hline
\end{tabular}




\begin{tabular}{|lc|}
\hline \multicolumn{1}{|c|}{ TABLE 11} \\
To Which Format for Scientific \\
Literature Will Your Library Be \\
Committing the Better Part of Its \\
Materials Budget?
\end{tabular}

quently centered on cost and relation to the college curriculum. Services available via a graphical user interface (GUI) proved most prevalent. Two of the newer services, Project Muse and JSTOR, were mentioned by seven participants. LexisNexis availability existed at only two colleges. Although Knight-Ridder Information Services is making more full-text databases available through its Dialog and Classroom Instruction Programs (CIP), participants showed a decline in the amount of usage for this well-established online service. One reason is that Dialog searching has required librarian mediation, whereas the databases available through GUI or Web-based interface are searchable by end users. Dialog sold its end-user version to CompuServe early in the 1990s. Many of the same Dialog databases are accessible through CIP at a markedly discounted rate as long as the subscribing institution limits use to course-related research. A Knight-Ridder representative informed the author that only five public and private institutions in Ohio subscribe to CIP. In the Ohio group, Ohio Wesleyan is the only member of the consortia that made up the study. ${ }^{9}$ CIP allows access to many periodicals (mostly business and general interest) and newspapers in full text. Neither full-service Dialog nor CIP offers any graphics with its full-text databases.

There were more disadvantages for turning to electronic journals by academic libraries. Respondents cited advantages as elimination of preservation/binding concerns, elimination of vandalism, the saving of space, and desktop access by users. Disadvantages included lack of serendipitous discoveries from browsing, expense for necessary hardware and software, uncertain connection to the curriculum, printing graphics, steep learning curve for staff and users, back file access, Internet dependency, paper consumption, and absence of standardized systems. Although such disadvantages are not insurmountable, they do require library administrators to think soberly about making a commitment to electronic journals.

Another question dealt with satisfaction with vendor and technical support from online vendors. Participants declared a general satisfaction with the services used. Although some problems were mentioned, they were not seen as major obstacles.

Among the additional points mentioned outside the study questions was staff development for the new electronic technologies. One director expressed concern over the steep learning curve for both staff and end users that will require attention. A central question articulated by one director was whether the vicious cycle of subscription price increases and title cancellations will ever cease. Comments received by publishers' representatives will address this issue below. The director and acquisitions librarian at one college pointed out the need for a regular cycle

\begin{tabular}{|c|c|}
\hline \multicolumn{2}{|c|}{$\begin{array}{c}\text { TABLE } 12 \\
\text { Would You Define Subscriptions to } \\
\text { Electronic Journals As an Act of } \\
\text { Securing Ownership or Allowing } \\
\text { Access to Required Scientific } \\
\text { Literature? }\end{array}$} \\
\hline Response & No. of Respondents \\
\hline Access & 15 \\
\hline Ownership & 2 \\
\hline Both & 3 \\
\hline
\end{tabular}


of journal review to stay on top of the problem. Another library director said she is paying particular attention to journal storage projects and how they may aid her situation.

\section{Responses from Publishers}

As the author discussed the problems associated with rising scientific journal costs with colleagues, it became apparent that a balanced report on this issue could not be achieved without seeking reaction from publishers. With emphasis on company size and reputation, Springer Verlag New York, Inc., and Elsevier Science, Inc., were contacted to represent commercial publishers. In addition, interviews were conducted with representatives of two nonprofit publishers of scientific literature, Annual Reviews Inc., and ACS. As it turned out, contact with a representative for Springer Verlag could not be made, although he did leave a phone-mail message expressing his sympathy for the libraries' plight. For those successfully reached, the purpose of the study was explained, and they were asked to address the issue from the publisher's perspective. In addition, the question as to any plans for special arrangements helpful to the budgetary situation of liberal arts college libraries was posed.

John Tagler, director of corporate communications with Elsevier Science, consented to the first telephone interview. He agreed that the gap between library budgets and subscription prices have been widening since the 1980s and explained that, from his company's perspective, liberal arts college libraries do not represent a large enough market to justify any special subscription packages. Moreover, he expressed the belief that there is no resolution to the cycle of subscription price increases and title cancellations. He echoed two of the publisher arguments made in the McCarthy article concerning the downward spiral of the dollar and the huge increase in the sheer volume of scientific literature being produced. Further, he said that for most Elsevier publications, there were approximately 700 to 1,000 subscribers worldwide per title. Given their esoteric content and such a limited market, there is no way to avoid the high subscription prices. The only hope he saw lay in libraries joining consortia such as OhioLINK, which just reached a group-licensing agreement with Elsevier for electronic access to 1,100 of its titles. In the early going, however, libraries will still need to find funds beyond what is budgeted to take advantage of such an innovation as the Elsevier/ OhioLINK service.

However, he did share information about possible future offerings that might give some relief. One is a program he called Science Direct that will make articles available electronically as either PDF or HTML files. Possibly available in 1998 , the plan is to include ownership for archival files. Apparently, Elsevier had considered a small institution package but had dropped it because of the difficulty in defining a small institution. He cited institutions with small enrollments but with highly technical, specialized curricula as complicating the issue. ${ }^{10}$

The first nonprofit contact was with Samuel Gubins, president and editor in chief of Annual Reviews Inc. It was his organization's doubling of its subscription rates last fall that heightened this author's interest in this issue. He replied to an e-mail query with a fax transmission of the letter that went out to Annual Reviews subscribers last fall. It explained the price increase and included personal comments on the situation. Until last fall, Annual Reviews had offered only one rate to both individuals and libraries. The letter described how the company's board of directors had decided that the time had come for institutional pricing if the organization was to maintain its long-term financial stability. It acknowledged with regret that no gradual price increase plan for institutions had been set up in recent years to alleviate the surprise of their announce- 
ment. His comments, which accompanied the copy of last fall's letter, described the successful attainment of financial stability. As a result, he declared that prices will not increase in 1998, and if sales do well, they will not increase in 1999. He concluded with descriptions of new offerings for Annual Reviews. One is electronic access to titles on an individual subscription basis. The Annual Review of Sociology and the Annual Review of Medicine are accessible electronically. The organization plans for electronic access to all its series during the next year for libraries subscribing to the print equivalents. Also under consideration are discounts on the purchase of multiple series of the Annual Reviews. For example, a library could subscribe to ten different series and get a discount of X percent. ${ }^{11}$

The second telephone contact with a nonprofit publishing body was with Peter Gaviorno, general manager of sales and marketing for ACS Publications. He covered much of the same ground as $\mathrm{Mr}$. Gubins in justifying ACS's subscription rates. He gave a breakdown of the rationale for a subscription price, explaining that 70 to 80 percent of the cost represents production and 20 to 30 percent covers postage. He also saw no immediate resolution to the cycle, saying that electronic alternatives to ACS publications will cost more in the short term. He did describe three special subscription plans currently available, but liberal arts colleges are not the prime beneficiaries. One plan grants a ten percent discount to institutions that subscribe to all thirty-four ACS publications. The second plan calls for a ten percent discount under what he called the "school plan" for seventeen particular titles. The third plan comes under the name "biochemistry/biotechnology plan" for six or seven titles, but he did not give the discount percentage. He mentioned that the marketing division is considering conducting analysis of its subscriber base through focus groups or the establishment of a library advisory panel. ${ }^{12}$

\section{Conclusions}

This study began with no expectation that any earthshaking facts about the impact of journal prices on library budgets would be discovered. The findings are not surprising, but much was learned from interviews with colleagues at similar institutions. All kinds of libraries-public, special, and academic - are trying to manage at various levels.

Some predictions about the journal price issue were confirmed, but others, however subtle, were altered. One centers on the level of library funding at private liberal arts colleges. Before this study, the author believed that most college libraries received funding at generally the same level. Thus, the difference among periodicals budgets at the libraries contacted was mildly surprising. Often it stems from the degree of support from the traditional sources of revenue for liberal arts colleges. Ohio Wesleyan, for example, like many other schools, experienced fiscally austere times in the 1990s, and other schools fared even worse. If periodical budgets were generally comparable, there were marked differences in other budget areas, such as the degree of information technology development, condition of the physical plant, and staffing level.

Another revelation concerned faculty and administrative awareness of the implications of the journal pricing issue. It was enlightening that faculty often do not know that publishers may have both individual and institutional subscription rates and that institutional rates are usually significantly higher.

Much was learned about tangential matters relating to academic librarianship such as the problems posed by campus computer infrastructure, the variety of computer platforms and software, the ramifications of the level of library instruction offered, and the dynamics among librarians, faculty, and administration. Although these concerns do not constitute the main thrust of the study, 
learning about them still influenced the study's focus. For example, the level of computer literacy among faculty and students is directly related to the benefit derived from electronic databases and journals. In addition, the capabilities of the campus computing system determines the degree to which online systems can be incorporated into the curriculum.

The process of resolution of subscription price increases between the library and the science departments is typically addressed through informal communication. The director contacts the chair of the department affected, or the library liaison contacts his or her counterpart in the department. Most contacts take place via telephone and, increasingly, e-mail. "Reluctant understanding" was the phrase that best characterized faculty reaction to library communications regarding the need to review subscriptions. All parties involved hate having to deal with the prospect of canceling titles when subscriptions increase in price or having to take time to review the importance each discipline's titles makes to the curriculum. Librarians conveyed the sense that they were "walking on eggs" when trying to manage the issue of journal price increases. The image of angry and/or disappointed monarchs slaughtering messengers bearing bad news came to mind more than once. Therefore, it would seem that librarians need to be more forthright in presenting the matter of journal price increases to their faculty. They should take a proactive approach to informing their faculties about what must be done. A more assertive approach from the library side will serve to dismiss any lack of understanding about journal price increases. Librarians can clear up any confusion about the differences between individual and institutional subscription rates on the faculty and administrative side.

A few libraries developed tools to help in the subscription review process. Tools can be defined as evaluation forms that include title costs, usage figures, a rating scale for relevance to the curriculum, or all these elements. These tools will help librarians and faculty resolve the matter of journal price increases as quickly, efficiently, and amicably as possible. The most effective example of such a tool was at the library where the director created a form with a one-to-four scale for judging a title's importance to the curriculum.

Because all indications are that the cycle of price increases and title cancellations will continue, findings point toward establishment of a formal process of journal subscription review as the best solution to this problem. A formal process brings faculty and library staff together to resolve a common problem. A periodic journal review dispels confusion about individual and institutional subscriptions, as well as any notions about blame. How such a process is actually implemented will depend on the campus political climate. Ideally, however, library and faculty should agree on a periodic review of all periodical subscriptions every two or three years. Such a period will provide enough time for new titles to establish a track record of usage and relevance to the curriculum. Initial setup of such a process will depend on support from the college's chief academic officer (provost, dean, or vice president for academic affairs) and from influential and respected faculty members who are strong library supporters. At the time of review, the library should be ready to provide an evaluation form giving the most recent price for a title, usage figures for circulation and inhouse use, and a rating scale mutually agreed upon with the faculty as to the journal's relevance to the curriculum. Armed with this information, the faculty can make informed judgments about what will be kept or canceled. All faculty should be involved in the process. Where departments are reluctant to cancel enough titles to reconcile the budget with the rise in subscription rates, library staff and departmental representatives will 
need to negotiate until a satisfactory agreement is reached.

Regarding the question of ownership versus access, ownership still "holds the edge" on access because of tradition and familiarity. However, there is a gradual movement toward access of electronic alternatives to print journals as they become more plentiful and affordable. User comfort with technology and campus support for continuing education are two primary factors in determining the rate at which access is embraced.

College libraries are turning to electronic databases and journals more and more. However, the level of dependence on these electronic services still trails the use of print materials significantly. Such services continue to expand awareness and access to literature in all disciplines. The author's own tour of the exhibits at the April 1997 ACRL Biennial Conference caused the sensation of one's head swimming in trying to sort out the volume of services now or soon to be offered in Webbased versions. Many more such products are in development, and such electronic services will continue to be a growing presence in the academic library landscape.

ILLactivity rose for many participants, but the reasons for the increase varied considerably. Based on the findings, increased ILL activity cannot be attributed directly to canceled scientific journals.

Use of document delivery services remains minimal. Participants use it as a last resort for hard-to-obtain items or when time is of the essence in getting an article.

To revisit the original question about the subscription rates for electronic journals being more affordable than print, the immediate answer is no. Publishers that can produce both print and electronic versions have the advantage in terms of pricing and marketing their products. Currently, the best answer from the college library side is for libraries to enter group-licensing agreements with publishers as OhioLINK did with Academic Press and Elsevier during the 1996-1997 academic year.
At present, group-licensing agreements for electronic journals are an additional, but modest, expense for academic library budgets. The hope lies in more publishers and libraries entering such agreements for electronic journals so that the cost will continue to decrease. Tom Sanville, OhioLINK's executive director, pointed out in a recent conference paper that the maximum institutional advantages of such modest incremental expenses should be clear to academic administrators. He went on to say that library users will use what is available. The words available and immediate are becoming increasingly synonymous. Sanville said that journals that publishers move into an electronic environment will receive more use and are likely to receive protection within library budgets. Publishers who avoid using the electronic medium as group licenses increase run the risk of having more of their titles canceled. He believes authors will find electronic journals more attractive vehicles for their work because of their increasing accessibility. Further, he reiterated that modest additional costs will be necessary in the early going but that such an initial investment will yield dividends in an explosion of use. He concluded his comments by observing that if neither vendor nor library becomes too greedy or fainthearted, the transformation of journal accessibility over the next several years will be profound. ${ }^{13}$ These are helpful comments from someone deeply involved with this issue. College libraries need to move more toward such collective action to find some degree of relief from escalating prices.

Librarians also must be proactive in expressing their concerns to publishers about the pressures resulting from rising subscription costs. They should contact marketing representatives, volunteer to participate in focus groups, or join advisory committees so as to have a voice in how the literature is made available. Librarians know what formats of literature 
are most useful to their users, and that information needs to be impressed on the publishing community. Group licensing shows very promising potential. Librarians, faculty, and administrators must be prepared to make the initial investment to ensure benefit from future savings.

This study indicates that the pressures of escalating scientific journal prices show no signs of abating. To guarantee collection quality in relation to the curriculum and to make the best use of existing journal funding, librarians and faculty need to agree on a formal and regular review process. The contribution of full-text databases and electronic journals still cannot compare to the value placed on print resources, but they are making positive and constructive inroads as a solution to the journal price dilemma. Group-licensing agreements for such electronic sources will expedite the development of more electronic resources. Only by becoming involved in group-licensing agreements in their infancy will college libraries realize any future savings and relief to the scientific journal subscription rate predicament.

\section{Notes}

1. Paul McCarthy, "Serial Killers: Academic Libraries Respond to Soaring Costs," Library Journal 119 (June 1994): 41-44.

2. Lee Ketcham and Kathleen Born, “Unsettled Times, Unsettled Prices," Library Journal 122, no. 7 (Apr. 1997): 42-47.

3. McCarthy, "Serial Killers," 41-42.

4. Chestalene Pintozzi, "Rethinking Scholarly Communication," College \& Research Library News 57 (Feb. 1996): 88-91.

5. McCarthy, "Serial Killers," 41-42.

6. Ulrich's International Periodical Directory. 4 vols. (New Providence, N.J.: Bowker, 1996).

7. Ibid.

8. Library Guidelines for ACS Approved Schools. Hp. 16 June 1997. Online. Available at: http:/ /www.acs.org/cpt/library.htm.

9. Laura Graham (Laura_Graham@krinfo.com), “Classroom Instruction Program." E-mail to Paul Burnam (pdburnam@cc.owu.edu), July 3, 1997.

10. John Tagler, telephone conversation with author, June 4, 1997.

11. Samuel Gubins, telefacsimile sent to author, June 3, 1997.

12. Peter Gaviorno, telephone conversation with author, June 23, 1997.

13. Thomas J. Sanville and Barbara A. Winters, "A Method Out of Madness: OhioLINK's Collaborative Response to the Serials Crisis" (paper presented at the NASIG Conference, Ann Arbor, Mich., May 30, 1997). 